\title{
Education triad in the context of the Covid-19 pandemic. Challenges and strategies
}

\section{Triada educaţiei în contextul pandemiei de Covid-19. Provocări şi strategii}

\author{
POPESCU Gabriela Adriana, profesor \\ Colegiu Tehnic Mătăsari \\ POPESCU Gabriela Adriana, Teacher \\ Mătăsari Technical College \\ E-mail: chimiematasari@gmail.com \\ ORCID iD: 0000-0003-3614-7242 \\ DOI: $10.46728 /$ c.18-06-2021.p295-299

\section{CZU: 37.064.1}

Rezumat: Parteneriatul şcoală - familie - comunitate (SFC) este dat de relaţiile de colaborare intre personalul şcolii şi familii, membrii comunităţii, organizaţii (companii, biserica, biblioteci, servicii sociale) pentru a implementa programe şi activități care să îi ajute pe elevi să reuşească absolvirea cu succes a studiilor. Operaţionalizarea mai clară a conceptelor de implicare şi de participare a părinţilor permite diferenţierea următoarelor aspecte:

- două tipuri de implicare a părinţilor şi anume spontană (porneşte de jos în sus) versus planificată (de sus în jos); cea din urmă se referă la intervenţii sau programe construite cu scopul de a rezolva problema insuficientei participări sau absenţei părinţilor;

- implicarea acasă - spre exemplu, o discuţie acasă despre activităţile de la şcoală şi implicarea la şcoală - de exemplu, participarea părinţilor în activităţile şcolii sau aspecte de organizare a activităţii şcolare:comunicarea cu şcoala, relaţia şcoală - părinţi.

Increderea este vitală pentru colaborare şi reprezintă un predictor pentru îmbunătăţirea rezultatelor şcolare.

Cuvinte cheie: triadă educațională, covid, parteneriat

Abstract: The school-family-community partnership (SFC) is given by the collaborative relationships between school staff and families, community members, organizations (companies, church, libraries, social services) to implement programs and activities to help students succeed in graduation. successful studies. The clearer operationalization of the concepts of parental involvement and participation allows the differentiation of the following aspects:

- two types of parental involvement, namely spontaneous (starts from the bottom up) versus planned (from the top down); the latter refers to interventions or programs built in order to solve the problem of insufficient participation or absence of parents; - involvement at home - for example, a discussion at home about school activities and involvement in school - for example, parents' participation in school activities or aspects of organizing school activities: communication with the school, school-parent relationship. Trust is vital for collaboration and is a predictor of improving school results.

Keywords: educational triad, covid, partnership

\section{Introducere}

Pandemia de COVID-19 a dus la închiderea şcolilor în 20 de ţări şi la închiderea unităţilor preşcolare în 19 ţări din Europa şi Asia Centrală. Acest lucru a afectat un număr total de 49,8 milioane de copii, începând de la preşcolari până la liceeni, care au avut parte de un ultim semestru şcolar foarte perturbat (în cazul în care acesta a existat totuşi), care a culminat cu închiderea şcolilor. 


\section{Context}

Implicarea în dezvoltarea şi educaţia copiilor are diferite efecte pozitive: note mai mari la limba maternă şi matematică, abilităţi îmbunătăţite de scriere şi citire, rată de prezenţă la şcoală mai bună, mai puţine probleme comportamentale. Din acest motiv, implicarea părinţilor, mai ales în condiţiile pandemice pe care le traversăm, reprezintă o modalitate de a ajuta copiii în tranziţia acestora prin adolescenţă, cu efecte pozitive semnificative. Pe de altă parte, există şi dubii referitor la fezabilitatea unor astfel de parteneriate. Cercetătorii, mai ales sociologii care se ocupă cu definirea relaţiilor de putere, sunt reticenţi în a înţelege parteneriatul ca atare, considerându-l drept o iluzie În aceste situaţii, cadrul teoretic este definit de următoarele aspecte:

- diferenţierea participării părinţilor după diferite criterii: părinţii cu venituri mici participă mai puţin la activităţi în şcoli decât cei cu venituri mai mari. Barierele pe care le întâmpină părinţii cu venituri mici sugerează că şcolile trebuie să dezvolte o nouă abordare pentru implicareaacestor părinţi;

- împărţirea tradiţională a rolurilor de părinte în funcţie de gen.

1.1. Provocări. Pandemia a afectat profund educaţia şi a agravat inechităţile sociale existente în regiune. Copiii din familii cu venituri reduse, copiii care locuiesc în zonele rurale cu infrastructură deficitară, copiii din cadrul minorităţilor etnice şi lingvistice, copiii cu dizabilităţi, copiii migranţi şi refugiaţi, copiii aflaţi în conflict cu legea, copiii şi tinerii care nu frecventează instituţiile educaţionale, băieţii şi fetele care locuiesc în condiţii dificile sau în cămine abuzive se confruntau deja cu bariere semnificative pentru participarea la educaţie şi învăţare şi aveau parte de educaţie şi de avantaje sociale mai reduse decât cei de aceeaşi vârstă.

Şcolile nu sunt doar un loc pentru educaţie academică, ci şi pentru învăţarea abilităţilor sociale şi emoţionale, interacţiune şi sprijin social. Închiderea şcolilor nu numai că a perturbat procesul de educaţie a copiilor, ci şi accesul la mese oferite în cadrul şcolii, sprijin pentru bunăstare şi referire la servicii medicale şi sociale de bază.

Provocarea care îi aşteaptă pe profesori, directori de şcoli, responsabili din sistemul de educaţ̧ie şi factori de decizie de la nivel local şi naţional este semnificativă. Dacă nu se va face faţă acestei provocări, impactul asupra copiilor, tinerilor, familiilor, comunităţilor și societăţilor la un nivel mai larg se va resimți pe tot parcursul vieții, atât din punct de vedere social, cât şi economic. De aceea, îmbunătățirea rezilienței sistemului educaţie, prin planificarea unei educaţii incluzive de calitate pentru cei mai marginalizaţi copii, ar trebui să fie o prioritate maximă pentru următoarele luni şi ani şi ar trebui să fie principiul de bază al reconstruirii unui învăţământ mai bun şi al unor şcoli mai bune.

1.2. Oportuniăţii. Astfel, sistemele de învăţământ trebuie să fie mai flexibile, complet dedicate tuturor copiilor, sisteme care educă printr-o varietate de modalităţi/metode şi tehnologii şi care sunt mai bine echipate pentru a face faţă unor posibile crize. Este necesar de a păstra şi de a promova învăţământul şi educaţia incluzivă de calitate pentru toţi copiii şi tinerii, în special pentru cei mai marginalizaţi copii, pe parcursul şi după fazele de izbucnire şi de recuperare în urma pandemiei de COVID-19, iar directorii de şcoli şi responsabilii din sistemul de învăţământ din cadrul autorităţilor locale, inspectoratelor şcolare judeţene şi ministerelor educaţiei trebuie sa apeleze la un cadru general şi un set de repere tematice pentru procesele de luare a deciziilor, de planificare şi de elaborare a politicilor.

In acest fel este încurajata comunitatea educaţională să adreseze inegalităţile majore în ceea ce priveşte accesul la furnizarea unei educaţii incluzive de calitate şi diferenţele semnificative de învăţare între grupurile de copii în timpul pandemiei de COVID-19, dar şi după aceasta. 
1.3. Implicarea comunităţii. Se referă la colaborarea cu grupuri şi lideri de la nivelul comunităţii, din societatea civilă, din guverne şi lideri de opinie; şi extinderea rolurilor colective sau ale grupurilor în adresarea aspectelor care afectează vieţile acestora. Implicarea comunităţii oferă putere grupurilor şi reţelelor sociale, dezvoltă diverse aspecte pe baza punctelor forte şi a capacităţilor locale şi îmbunătăţeşte participarea, asumarea, adaptarea şi comunicarea locală.

Realizarea procesului de educaţie este, de obicei, influenţată de factori care funcţionează pe patru niveluri:

1. Copilul şi familia: gen, etnie, venit, sănătate, mobilitate;

2. Şcoala: resurse, practici de predare şi învăţare, etos, îngrijire şi sprijin;

3. Comunitatea: relaţiile şcoală-comunitate, implicarea autorităţilor locale, a societăţii civile;

4. La nivel naţional: politici, investiţii, norme sociale şi de gen.

Reconstruirea unei educaţii mai bune înseamnă abordarea factorilor de excluziune ca o prioritate şi abordare la nivelul tuturor celor patru niveluri simultan. Reconstruirea unei educaţii mai bune nu înseamnă doar un plus pentru copiii cei mai marginalizaţi, înseamnă şi asigurarea faptului că eforturile naţionale şi locale converg pentru a sprijini transformarea şcolilor, cu accent pe două aspecte esenţiale:

- Transformarea pedagogiei prin dezvoltarea unui curriculum şi a unor practici instructive mai incluzive şi mai flexibile, care să răspundă nevoilor individuale ale fiecărui copil;

- Transformarea etosului şcolar, a structurilor şi organizării şcolare astfel încât incluziunea, îngrijirea, respectul şi sprijinulholistic să constituie misiunea principală a şcolilor.

\section{Implicarea şcolii}

Predarea la distanţă în situaţii de urgenţă (sau învăţarea la distanţă în situaţii de urgenţă ilustrează situația în care cursurile sunt oferite prin învăţare la distanţă, ca răspuns la o criză, mai degrabă decât să fi fost planificate sau organizate în scopul educaţiei la distanţă. Recuperarea este utilizată în document pentru a indica revenirea la o stare normală. „Recuperarea procesului de învăţare" presupune paşi şi intervenţii pentru a adresa pierderile din procesul de învăţare din cauza închiderii şcolilor şi a pandemiei. „Etapa de recuperare după COVID-19” se referă la reîntoarcerea la viaţa aşa cum o ştiam noi sau la o viaţă strâns legată de cea pe care o aveam înainte de pandemie.

Ținând cont de acest obiectiv, actorii principali din sistemul de educaţie pot rămâne fideli misiunii şi obiectivului lor pe termen lung de a permite tuturor copiilor să-şi conştientizeze dreptul la educaţie şi să-şi atingă potenţialul maxim. Este posibil ca factorii de decizie din domeniul educaţiei să nu deţină controlul asupra deciziilor politice cu privire la măsuril e naţionale de sănătate şi de protecţie, dar se pot concentra pe ceea ce ştiu, pe ceea ce pot controla şi pe ce au competenţă, adică să-i înveţe pe elevi cum să se protejeze de virus, să se concentreze pe nivelul calităţii actului de predare-învăţare, pe furnizarea serviciilor de educaţie incluzivă şi atentă şi pe bunăstarea forţei de muncă din domeniul educaţiei. Deşi actorii din sistemul de educaţie nu au mijloacele sau mandatul de a aborda toate circumstanţele posibile pentru copiii şi familiile lor, acești a au puterea şi datoria de a se asigura că fiecare copil este binevenit la şcoală si apreciat.

\section{Parteneriatul pentru învățare}

Trăim într-o societate în care ritmul rapid de desfăşurare a evenimentelor determină o schimbare permanentă a realităţii. Iată de ce, fiind parte integrantă a acestui mecanism în continuă mişcare, de multe ori simţim nevoia să găsim o bază solidă la care să ne raportăm, pe care să ne regăsim liniştea şi pe care să ne putem bucura de un moment de răgaz. În educaţie, această bază poate fi reprezentată de stabilirea unor relaţii solide între toţi factorii implicaţi în educaţie: şcoala, familia şi comunitatea, adica formarea unui parteneriatul pentru învăţare. 
Parteneriatul pentru învăţare are ca scop găsirea de modalităţi de a îmbunătăţi şi consolida relaţiile şcoală-familiecomunitate. De aceea, este necesar să se organizeze sesiuni de instruire în care participanţii aparţintuturor categoriilor vizate: profesori, părinţi, membri ai comunităţii, elevi cu vârsta de peste 16 ani. În timpul acestor sesiuni de formare, cursanţii vor învăţa despre modalitaţi şi strategii eficiente de a consolida relaţiile şcoală-familie-comunitate punandu-se accent pe manegementul comunicării.

\subsection{Importanţa comunicării}

Comunicarea eficientă este piatra de temelie a educației. Comunicarea eficientă este una dintre caracteristicile obligatorii pentru a deveni director de şcoală/profesor /educator eficient şi de succes.

Profesorii au punctat faptul că părinții întâmpină multe bariere și au puţine oportunităţi de implicare în viaţa şcolii. Colectarea de informații și comunicarea între părinți și profesori în ceea ce privește preferințele individuale, eficacitatea și barierele în calea implicării sunt discutate ca premise importante pentru stabilirea unor parteneriate eficiente între familie şi școală. Sophia Catsambis și Janet E. Garland punctează faptul că implicarea părinţilor scade dramatic atunci când elevii intră în clasele de gimnaziu și, cu atât mai mult, când aceştia intră la liceu. Aceste modificări nu înseamnă că părinții îşi pierd interesul pentru educaţia copiilor lor.

\section{a. Rolul părinţilor}

Există o serie de motive pentru care implicarea părinților în activităţi coordonate de şcoală este mai mult decât recomandată. Implicarea părinților îmbunătățește performanțele şcolare ale copiilor. Cu cât părintele este implicat mai mult, cu atât şansa de succes şcolar a copilului este mai mare. Implicarea părinților duce la un comportament al copiilor în clasă mai bun.

Se observă că implicarea părinţilor tinde să scadă înînvăţământul secundar. Factorii care determină lipsa deimplicare a părinţilor sunt: lipsa reţelelor sociale pentrupărinţi, lipsa stabilităţii financiare, nivelul educaţional scăzut al părinţilor, factori ce ţin de şcoală, ore de întâlnireneconvenabile, transport, îngrijirea copiilor, cunoştinţelepărinţilor despre regulile şi politicile şcolii, lipsa de încredere a şcolii în părinţi şi elevi, rasismul perceput de către părinţi, experienţe negative ale părinţilor cu şcoala în copilărie.

Încrederea între indivizi sau între grupurile dintr-o organizaţie este semnificativă pentru stabilitatea pe termen lung a organizaţiei şi pentru starea de bine a membrilor săi . Se consideră că dezvoltarea armonioasă a unui copil nu este numai preocuparea părinţilor, ci şi a societăţii în ansamblu, prevăzută în sistemele legislativ, financiar şi de protecţie socială. Instituţionalizarea educaţ̧ionalăa copiilor în ţările nordice este clar reglementată, responsabilipentru educaţia copiilor fiind deopotrivă familia şi statul. Graniţele între şcoală şi familie sunt tot mai neclare, iar şcolile aufost nevoite să îşi redefinească obligaţiile şi să delege mai multeresponsabilităţi familiei. Parteneriatul familie - şcoală este dorit şi înţeles aproape de la sine în dezbaterea publică şi în cercetare. In practică, însă nu sunt întotdeauna atât de clare responsabilităţile fiecărui actor .

\section{b. Rolul directorilor}

Un rol esenţial în facilitarea parteneriatelor FSC îl au structurile manageriale şi directorii şcolilor. Este accentuată ideea importanţei unei abordări coordonate, care include şcoalaşi familiile pentru succesul educaţiei copiilor (Bernal et al. 2011).Ca şi consilierii şcolari, directorii sunt de asemenea ,invitaţi” să îşi regândească rolul în ceea ce priveşte conducerea personaluluişcolii şi modul de organizare a rolurilor şi relaţiilor. Un model popular de leadership este acela al şcolii care învaţă, unde procesul decizional este activ împărtăşit între personal, elevi şi familii. Directorii trebuie să regândească graniţele între şcoli prindezvoltarea unor centre de servicii integrate la nivel de şcoalăsau prin sprijinirea dezvoltării echipelor de coordonare a ofertelor de servicii la nivel comunitar pentru a oferi elevilor un acces mai mare la servicii complexe (Amatea şi Clark, 2005). 


\section{c. Rolul comunităţii}

Există o serie de studii, axate pe dacă şi cum implicarea familiei influenţează succesul elevilor în şcoală. Rezultatele sugerează că implicarea familiei contribuie la îmbunătăţirea rezultatelor, frecvenţei şcolare şi o mai mare responsabilitate a elevilor pentru munca legată de şcoală Implicaţiileacestor rezultate pentru şcoli ţin de faptul că, dacă acestea doresc să dezvolte parteneriatul cu părinţii şi să îmbunătăţească succesul elevilor, atunci trebuie să regândească rolul familiei şi implicării comunitare. Şcolile trebuie să planifice programe de parteneriat care să stabilească legătura dintre familie şi şcoală în cadrul activităţilor care încurajează succesul elevilor. Deşi cooperarea dintre familie şi şcoală este parţial cerută prin lege, cooperarea dintre familie şi şcoală este analizată din perspectiva contextului traumatic al transformărilor sociale dramatice generate de pandemia de Covid 19. Procesele de schimbare sunt reprezentate prin contradicţii, confuzii, tensiuni, lipsa resurselor şi lipsa angajamentului. Atunci când se schimbă identităţile grupurilor şi când sfera socio-psihologică a funcţionării de zi cu zi este schimbată dramatic, părinţii şi profesorii sunt provocaţi să caute noi soluţii .

\section{Concluzii}

Părinţii au un rol esenţial în sprijinirea educaţiei copiilor prin colaborarea cu şcoala şi comunitatea. Serviciile de consiliere şcolară pot sprijini crearea unor parteneriate eficiente şcoală - familie - comunitate. Cu toate acestea, cercetările evidenţiază o serie de bariere culturale, psihologice şi sociale, care pot limita sau bloca colaborarea dintre şcoală - familie - comunitate (SFC). Parteneriatul şcoală - familie - comunitate (SFC) este abordat ca o relaţie prin intermediul căreia personalul şcolii implică familia şi alţi membri ai comunităţii în vederea susţinerii copiilor pentru a avea succes şcolar. Acesta presupune colaborarea între personalul şcolii şi familii, membrii comunităţii, organizaţii, spre exemplu: companii, biserică, biblioteci, servicii sociale, etc. pentru a implementa programe şi activităţi în beneficiul elevilor.

\section{BIBLIOGRAFIE}

1. Parteneriatul şcoală-familie-comunitate - Laboratorul Consiliere şi management educaţional ISE, 2014

2. ANTONOWICZ Laetitia. Crearea unor sisteme de educaţie reziliente în contextul pandemiei de COVID-19 -UNICEF

3. BĂRBULESCU A.-G. Strategii-de-consolidare-a-cooperarii-scoala-familie-comunitate. Editura Sfầntul Ierarh Nicolae, 2014 